\title{
FUNGSI SENI GEMBYUNG DALAM KEHIDUPAN MASYARAKAT PANJALU KABUPATEN CIAMIS
}

\author{
Oleh Endang Supriatna \\ Balai Pelestarian Sejarah dan Nilai Tradisional Bandung \\ Jln. Cinambo No. 136 Ujungberung Bandung \\ Email: supriatnaraihan@ymail.com
}

Naskah diterima: 30 Juni 2010

Naskah disetujui: 6 September 2010

\begin{abstract}
Abstrak
Gembyung sebagai kesenian buhun yang menjadi sebuah seni pertunjukan di Panjalu, hingga kini tetap bertahan dengan ciri ketradisionalannya. Bersama dengan pelaksanaan Upacara Nyangku maupun peringatan Maulid Nabi Saw. atau pada acara hiburan pada saat khitanan anak, Gembyung tampil bersahaja. Namun demikian, penampilannya tetap menyampaikan makna baik melaui gerak, lagu, gending musik, maupun sesajennya bahwa hidup akan terus bergerak seiring berlangsungnya sang waktu. Bagi masyarakat Panjalu, Seni Gembyung tidak hanya sebuah ungkapan ekspresi keindahan, namun lebih dari itu, Gembyung memiliki makna kecintaan serta penghormatan kepada asal-usul leluhur mereka. Tulisan ini berupaya mengupas fungsi Seni Gembyung pada masyarakat Panjalu. Ada dua bagian yang dibahas, pertama gambaran sosial budaya masyarakat Panjalu tempat kesenian ini tumbuh. Kedua, menjelaskan Seni Gembyung, mulai dari perkembangannya, lagu dan teknik pementasan, fungsi dan peranan kesenian ini pada masyarakat pendukungnya. Serta, upaya masyarakat Panjalu memelihara Seni Gembyung agar tidak tergerus oleh seni modern yang semakin deras berupaya menggeser seni lokal. Tulisan ini menggunakan metode deskriptif dengan pendekatan kualitatif.
\end{abstract}

Kata kunci: Seni Gembyung, tradisi masyarakat, Panjalu.

\begin{abstract}
Gembyung is a kind of traditional performance art in Panjalu that has a long history. Along with Nyangku ceremony or commemoration of Maulid Nabi Saw. (the birth of prophet Muhammad Saw.), or celebration after a child has circumsized, gembyung is played in a very plain way. The mystical music and the fragrance of the offerings accompanied the dancers in expressing their respect to the ancestors. This paper tries to reveal the function of gembyung art in the society of Panjalu. There are two parts to be discussed: firstly, the description of sociocultural setting of Panjalu society where the art has been developed. Secondly, explanation of gembyung art, beginning with the development, the songs, and the performance techniques. A descriptive method and qualitative approach were conducted in this paper.
\end{abstract}

Keywords: Art Gembyung, community traditions, Panjalu. 


\section{A. PENDAHULUAN}

Setiap mengembangkan kesenian sebagai ungkapan naluri estetika sejalan pandangan, aspirasi, kebutuhan, dan gagasan-gagasan yang mendominasinya. Proses pemuasan kebutuhan estetika berlangsung dan diatur oleh seperangkat nilai serta norma yang berlaku di masyarakat. Oleh karena itu, ia cenderung untuk direalisasikan dan diwariskan kepada generasi berikutnya. Biasanya inti nilainilai dan asas-asas ini jarang bisa berubah kecuali jika perangkat nilai dan asas tersebut pada masanya tidak lagi berfungsi secara serasi atau diterima akal para pendukungnya.

Suryana, J. (2002) menyebut kesenian di atas sebagai kesenian tradisi atau tradisional. Ia membedakan kesenian ke dalam kesenian tradisi dan kesenian masa kini (modern). Selanjutnya ia menjelaskan, kesenian tradisi didukung oleh masyarakat yang memiliki sikap yang terikat pada aturan adat. Semua kegiatan yang berciri tradisi cenderung lambat berubah. Di dalam tradisi ada ketentuan norma, baik tertulis maupun tidak tertulis, yang harus dipatuhi anggota masyarakat tradisi. Ketentuan tersebut biasanya dilengkapi sanksi tertentu bagi mereka yang melanggarnya. Dengan demikian, bentuk seni tidak perlu berubah selama makna seni yang berkaitan dengan pandangan hidup masyarakatnya masih tetap.

Jawa Barat memiliki kesenian daerah yang berciri khas Sunda sebagai ciri khas kemajemukan kesenian di bumi Nusantara. Seni Gembyung adalah salah satu bentuk kesenian daerah yang masih eksis, terutama masih tumbuh subur pada masyarakat yang bercirikan tradisional tadi. Seni Gembyung masih bertahan pada masyarakat Sumedang, Subang, Cirebon, dan Kabupaten Ciamis, khususnya pada masyarakat Kecamatan Panjalu. Kesenian Gembyung adalah pertunjukan yang mempergunakan terebang besar, dimainkan untuk memeriahkan peringatan Maulud Nabi Muhammad Saw. maupun untuk keperluan lain. Kesenian Gembyung merupakan pengembangan dari Seni Terebangan yang berasal dari daerah Cirebon dan digunakan sebagai alat menyebarkan agama Islam. Dengan demikian Seni Gembyung memiliki unsur religi yang cukup kental.

Jika dilihat dari unsur religi, antara Seni Terebang dengan Seni Gembyung yang hidup di Sumedang dan di Subang, maka Seni Terebang memiliki unsur religi yang lebih dominan dibanding dengan Seni Gembyung. Pada Seni Gembyung yang lebih ditonjolkan adalah seni hiburan walaupun tidak meninggalkan sisi ketradisionalannya. Selanjutnya, Seni Gembyung di Sumedang berkembang menjadi Seni Bangreng, yang lebih menonjolkan lagi unsur hiburan. Akan halnya Seni Gembyung di Subang, hingga kini masih dapat bertahan. Bahkan segi ketradisionalannya masih dapat dipertahankannya hingga kini (Lina, 2007:731).

Kesenian Gembyung tidak semata-mata sebagai sarana mengungkap rasa seni, melainkan juga untuk mengungkapkan emosi keagamaan atau aktualisasi sistem keyakinan mereka. Sistem keyakinan masyarakat Panjalu bersumber dari agama Islam yang telah diterima oleh hampir sebagian besar masyarakatnya. 
Kehidupan masyarakat Panjalu dapat dikatakan masih memegang kepercayaan warisan karuhun 'leluhur' mereka.

Untuk itu, ada beberapa permasalahan yang akan diungkap dalam tulisan ini, yaitu: Apa sajakah fungsi Kesenian Gembyung pada masyarakat Panjalu? Bagaimana pandangan masyarakat terhadap Seni Gembyung? Adakah perubahan pada seni ini jika dilihat dari perjalanan waktu? Serta, apa sajakah upaya masyarakat Panjalu dalam memelihara kesenian ini?

Tulisan ini ingin menjelaskan beberapa gambaran tentang Seni Gembyung yang menjadi bagian dalam Upacara Nyangku yang selalu dilaksanakan oleh masyarakat Panjalu. Selain itu, ingin memberikan gambaran tentang keberadaan Seni Gembyung yang tetap eksis hingga kini pada masyarakat Kampung Cibungur, Kecamatan Panjalu, Kabupaten Ciamis.

Tulisan ini berupaya mengupas masalah fungsi Seni Gembyung pada masyarakat Panjalu. Ada dua hal yang akan dijelaskan, yaitu berupaya menjelaskan gambaran Kampung atau Dusun Cibungur, Kecamatan Panjalu, Kabupaten Ciamis yang merupakan tempat kesenian ini tumbuh dalam wilayah masyarakat pendukungnya. Adapun penjelasan kedua, yaitu berupaya menjelaskan gambaran sosial budaya masyarakatnya yang berkenaan dengan asal-usulnya, perkembangan, kepercayaan atau mitos-mitos masyarakat tentang kesenian ini, teknik dan bentuk pementasan, organisasi perkumpulan kesenian, serta fungsi dan peranan kesenian ini pada masyarakat pendukungnya.

\section{B. HASIL DAN BAHASAN}

Masyarakat Desa Panjalu punya upacara khas dan selalu dilaksanakan dengan meriah setiap tahun, yaitu Upacara Nyangku. Peringatan ini khidmat dan sakral bagi masyarakat setempat maupun masyarakat asal Panjalu di luar Kota Ciamis. Upacara ini intinya adalah untuk membersihkan benda-benda pusaka peninggalan leluhur Panjalu yang tersimpan di Bumi Alit, sebuah museum lokal milik warga Panjalu. Upacara Nyangku merupakan tradisi masyarakat setempat untuk menghormati leluhur raja Panjalu bernama Borosngora yang biasa dilaksanakan setiap bulan Maulud, pada minggu keempat (hari Senin atau Kamis akhir bulan Maulud).

Upacara Nyangku secara rutin dilaksanakan setiap tahun pada bulan Maulud atau pada bulan Rabiul Awal, sesudah melaksanakan peringatan Maulud Nabi Muhammad Saw. Upacara tersebut merupakan peristiwa budaya yang khas dan unik karena ternyata bisa dipandang sebagai alat pemersatu dan ajang silaturahmi warga masyarakat yang sudah menyebar ke berbagai tempat di luar Kecamatan Panjalu, Kabupaten Ciamis, Provinsi Jawa Barat. Pada hari yang telah ditentukan mereka menyempatkan datang ke Panjalu, bahkan ada yang beberapa hari sebelumnya turut serta membantu mempersiapkan kebutuhankebutuhan untuk berlangsungnya upacara tersebut.

Bukan hanya warga Panjalu Ciamis Utara,yang menikmati upacara ini, karena warga dari luar Kota Ciamis pun hadir menyaksikan jalannya upacara. Itulah sebabnya setiap perayaan Nyangku, Desa Panjalu 
menjadi meriah. Bukan hanya upacaranya yang khidmat dan berkaitan dengan adat istiadat yang masih dipegang teguh masyarakat setempat, melainkan juga karena upacara itu telah berkembang menjadi sebuah arena hiburan rakyat setiap tahun. Bagi masyarakat Panjalu, Upacara Nyangku tak kalah meriah dengan Upacara Panjang Jimat di Cirebon.

Beberapa hari sebelum acara puncak, alun-alun Desa Panjalu sejak pagi hingga malam hari ramai oleh pengunjung. Masyarakat datang untuk berbelanja makanan dan pakaian, atau menikmati hiburan sederhana: ombak banyu, doger monyet, korsel, dan hiburan dangdut yang sangat digemari masyarakat setempat. Panjalu menjadi hingar bingar. Sehari sebelum Nyangku, dilaksanakan peringatan Isra Miraj Nabi Muhammad Saw. di rumah tokoh masyarakat Panjalu sekaligus Ketua Yayasan Borosngora, H.R. Atong Cakradinata.

Nyangku dimulai sejak Senin pagi. Masyarakat berebut ingin menyaksikan benda pusaka dikeluarkan dari museum. Mereka terlebih dahulu berkumpul di sepanjang Situ atau Danau Lengkong. Jika pinggiran danau itu sudah penuh, masyarakat yang tidak kebagian tempat, berkumpul di dekat Bumi Alit karena dari tempat inilah benda-benda pusaka warga Panjalu akan diarak ke Situ Lengkong untuk dibawa menuju makam Prabu Borosngora di Nusa Gede, sebuah pulau yang dikelilingi oleh Situ Lengkong. Sekitar pukul sembilan pagi itu, dengan amat hati-hati, benda-benda peninggalan leluhur yang terdiri atas pedang, cis, kujang, dan benda pusaka lainnya, diturunkan dari Bumi Alit, kemudian diarak menuju Nusa Gede di Situ Lengkong.

Benda pusaka berikut pengiringnya, menyeberang menggunakan sampan. Tiba di Nusa Gede, sebelum benda pusaka dibersihkan, terlebih dahulu diperlihatkan kepada para pejabat dan pengiring oleh sesepuh Panjalu Rd. H. Atong Cakradinata. Selanjutnya benda pusaka dibersihkan dengan air tawar yang berasal dari beberapa sumber mata air di Panjalu, termasuk air dari Situ Lengkong. Usai dibersihkan, benda pusaka dibungkus kembali dengan daun kelapa kering dan dibalut dengan benang kanteh kemudian dimasukkan kembali ke sarungnya masing-masing yang terbuat dari kain. Setelah selesai dibersihkan di tempat ini (Nusa Gede), benda-benda ini di arak menuju ke Bumi Alit untuk disimpan kembali.

Setelah benda pusaka kembali disimpan di museum, masyarakat yang memenuhi pinggiran Situ Lengkong pun bersuka ria. Mereka naik perahu tempel keliling Situ Lengkong, rekreasi sepuasnya, dengan ongkos per orang Rp 5.000,00. Penghasilan tambahan bagi pengemudi perahu-perahu itu, karena pada hari biasa penumpangnya tidak sebanyak hari yang khusus itu. Demikian pula hari Minggu, tak sebanyak pada hari Nyangku.

R. H. Atong Cakradinata, ketua umum Yayasan Borosngora menjelaskan, pada prinsipnya Nyangku hanyalah upacara adat yang sudah mentradisi. Upacara itu merupakan lambang penghormatan masyarakat Panjalu kepada leluhur mereka yang telah berjuang di masa lampau. Ada pula sisi lain yang ingin diraih dari Upacara Nyangku, yakni upacara ini 
dapat membangkitkan suasana haru bagi masyarakat Panjalu. Benda-benda pusaka yang selalu dimandikan setiap tahun itu, mereka yakini sebagai peninggalan Prabu Sanghiang Borosngora. Ia Raja Panjalu yang dikenal bijaksana dan pertama kali menyebarkan agama Islam di daerah itu.

Prabu Borosngora, atas perintah ayahandanya Prabu Sanghiang Cakradewa, berguru agama Islam kepada Sayidina Ali di Mekah. la berangkat ke tanah suci dengan membawa seperangkat pakaian raja, pedang dan sebilah cis. la pun membawa sebuah gayung yang dilubangi bawahnya. Konon, Sayidina Ali kemudian mengisi gayung itu dengan air zam-zam ketika Borosngora pulang ke Panjalu. Menurut legenda masyarakat setempat, air zam-zam itulah yang menjadi cikal bakal air Situ Lengkong sekarang. Situ Lengkong luasnya sekitar 50 hektar dengan sebuah pulau (Nusa Gede) di tengahnya seluas 16 hektar, keduanya merupakan cagar alam yang dijaga kelestariannya.

Sebagai tradisi, Nyangku merupakan warisan yang harus dijaga dan dilestarikan. Namun sebagai hasil akulturasi dan proses negoisasi budaya dan agama, Nyangku harus dimaknai sebagai nilai-nilai yang dapat diadaptasi tanpa harus berbenturan nilai-nilai agama. Bagaimanapun, akulturasi dan negoisasi adalah proses yang belum selesai, merupakan tugas ulama memperjelas peran Islam di setiap aspek dan hasil dari semua proses tersebut.

Pengaruh pembangunan modernisasi, serta masuknya unsur-unsur budaya luar, tampaknya belum menyebabkan terjadinya pergeseranpergeseran, baik dalam bentuk, isi, maupun fungsi upacara tersebut. Fungsi Upacara Nyangku bagi masyarakat pendukungnya dari dahulu sampai kini tidak mengalami perubahan. Dengan demikian upacara tersebut masih menunjukkan fungsi spiritual, yaitu sebagai ungkapan rasa syukur kepada Allah SWT untuk memohon ketenangan, ketentraman, dan kebahagiaan hidup lahir batin.

\section{Seni Gembyung}

Enoch Atmadibrata (1983: 31) menjelaskan bahwa Seni Gembyung adalah Seni Terebang yang telah dikombinasi/dikombinir dengan alatalat bunyi-bunyian antara lain: empat buah terebang, kendang dan kulanter, goong dan kempul, saron, dan rebab. Kesenian Gembyung cukup luas dikenal di Jawa Barat, misalnya di Kabupaten Kuningan terdapat di Linggarjati, Cilimus, Setianagara, Linggasana, Caracas, Panawangan, serta di tempat lain seperti: Kabupaten Subang, Sumedang, Cirebon, dan Tasikmalaya.

Di Kabupaten Sumedang, Atmadibrata selanjutnya menjelaskan, Kesenian Gembyung berkembang menjadi Kesenian Bangreng, yaitu kependekan dari terebang dan ronggeng. Instrumen Seni Gembyung yaitu 5 buah gembyung atau terebang besar, kendang dan kulanter, goong dan kempul, 2 buah saron, rebab atau terompet sebagai pembawa melodi. Pada Seni Gembyung terdapat Ronggeng yang selain bertugas sebagai sinden, juga menari.

Sebagian ahli berpendapat bahwa Seni Gembyung berasal dari Cirebon. Seni Gembyung merupakan 
salah satu kesenian peninggalan para wali di Cirebon. Seni ini merupakan pengembangan dari Kesenian Terebang yang hidup di lingkungan pesantren. Seperti halnya Kesenian Terebang, Gembyung digunakan oleh para wali yang dalam hal ini Sunan Bonang dan Sunan Kalijaga sebagai media untuk menyebarkan agama Islam di Cirebon. Kesenian Gembyung ini biasa dipertunjukkan pada upacara-upacara kegiatan agama Islam seperti peringatan Maulid Nabi, Rajaban dan Kegiatan 1 Syuro yang digelar di sekitar tempat ibadah. Kapan kesenian ini mulai berkembang di Cirebon tak ada yang tahu secara pasti. Kesenian Gembyung muncul di daerah Cirebon setelah Kesenian Terebang hidup cukup lama di daerah tersebut. Gembyung merupakan jenis musik ensambel yang didominasi oleh alat musik yang disebut waditra. Meskipun demikian, di lapangan ditemukan beberapa Kesenian Gembyung yang tidak menggunakan waditra terompet.

Setelah berkembang menjadi Gembyung, tidak hanya eksis di lingkungan pesantren, karena pada gilirannya kesenian ini pun banyak dipentaskan di kalangan masyarakat untuk perayaan khitanan, perkawinan, Bongkar Bumi, Mapag Sri, dan lainlain. Pada perkembangannya, kesenian ini banyak dikombinasikan dengan kesenian lain. Di beberapa daerah wilayah Cirebon, Kesenian Gembyung telah dipengaruhi oleh Seni Tarling dan Jaipongan. Hal ini tampak dari lagulagu Tarling dan Jaipongan yang sering dibawakan pada pertunjukan Gembyung. Kecuali Gembyung yang ada di daerah Argasunya, menurut catatan Abun Abu Haer, seorang pemerhati Gembyung Cirebon, sampai saat ini Gembyung masih dalam konteks seni yang kental dengan unsur keislamannya. Ini menunjukkan masih ada Kesenian Gembyung yang berada di daerah Cirebon yang tidak terpengaruh oleh perkembangan masyarakat pendukungnya.

\section{Asal-Usul Seni Gembyung di Panjalu}

Para sesepuh Seni Gembyung di Panjalu tidak satu kata ketika harus menyebutkan siapakah tokoh yang mula-mula 'membawa' atau menyebarkan Seni Gembyung di Panjalu. Terdapat banyak sumber yang mereka sebutkan, salah satu sumber menyebutkan bahwa Kesenian Gembyung mulai dikenal di Desa Panjalu kira-kira pada tahun 1920. Kesenian ini berasal dari Tasikmalaya. Ada pula sebagian tokoh setempat yang menyebutkan berasal dari Cirebon yang berangsur-angsur masuk ke Panjalu. Konon, menurut penuturan para leluhur seniman Gembyung di Panjalu menyatakan bahwa Gembyung diperkenalkan oleh orang-orang Islam dari wilayah tersebut, sambil berniaga mereka mengenalkan kesenian tersebut kepada warga setempat. Orang-orang Panjalu pun mulai mempelajari Kesenian Gembyung dan mengajarkan kembali kepada orang lain.

Sumber lain menyebutkan bahwa orang pertama yang mempelajari Seni Gembyung adalah Bapak Kadir dan Bapak Kiai Achyar. Atas inisiatif mereka berdua didirikanlah Grup Seni Gembyung lalu mengajarkannya kepada orang-orang yang datang dan ingin berguru kepada mereka. Dengan demikian masyarakat Panjalu menganggap bahwa Kesenian Gembyung merupakan warisan para karuhun 
'leluhur' secara turun- temurun. Proses belajarnya dengan cara mengikuti atau meniru yang dimainkan oleh orang tua mereka.

Menurut penuturan Bapak Udi (67 tahun), yaitu pemimpin kelompok Seni Gembyung di Desa Rumalega, ketika itu ia belajar atau berguru Seni Gembyung kepada Bapak Wikarta (sekarang sudah meninggal), ketika itu banyak teman-teman sebayanya ikut belajar kepada Bapak Wikarta. Dengan cara ini, maka regenerasi berjalan secara terus-menerus. Bagi masyarakat setempat, jika ada kegiatan keagamaan atau aktivitas masjid, merupakan sarana pembelajaran Seni Gembyung. Hal ini sudah menjadi tradisi masyarakat di Desa Panjalu. Setiap kali diadakan upacara peringatan Maulid Nabi Muhammad, masyarakat di Desa Panjalu berkumpul di masjid dan dipertunjukkan Seni Gembyung.

Dengan demikian, pada awalnya seni ini diperuntukkan dalam peringatan Maulid Nabi. Seiring dengan perjalanan waktu pula, ternyata Seni Gembyung juga dipertunjukkan untuk merayakan upacara menyambut bayi yang baru lahir, yang biasa disebut Marhaba. Pada upacara ini dilaksanakan pengguntingan rambut bayi dan memberikan nama bagi bayi yang baru lahir. Tempat pelaksanaan upacara di rumah orang tua sang bayi .

Pertunjukan Seni Gembyung yang paling utama yaitu pada upacara Maulid, yaitu mengumpulkan bendabenda pusaka seperti golok, tombak, pedang, keris dan sebagainya. Bendabenda pusaka ini setiap bulan Maulid dibersihkan dengan mengadakan upacara. Pada kesempatan itu pula Seni Gembyung kemudian dipertunjukkan.
Dari kebiasaan ini kemudian Seni Gembyung digunakan untuk merayakan Upacara Nyangku. Upacara Nyangku bagi masyarakat Panjalu sangat penting.

Kelompok Seni Gembyung yang dipimpin oleh Bapak Udi berjumlah 15 orang. Para pemain rata-rata sudah berusia lanjut, sekitar 60 tahun ke atas. Kalaupun ada pemain yang masih berusia muda, paling hanya satu dua orang saja yang berusia sekitar 45 tahun. Namun demikian para pemain 'muda' ini sering kali hanya berstatus sebagai pendamping.

\section{Instrumen Seni Gembyung}

Alat-alat atau instrumen, atau dalam istilah karawitan Sunda disebut waditra yang terdapat pada Seni Gembyung termasuk ke dalam kelompok waditra struktural. Artinya, dalam penyajian Seni Gembyung, waditra tersebut membentuk suatu permainan alat (waditra) berdasarkan bentuk gending dalam bunyi masingmasing waditra yang membentuk suatu jalinan komposisi untuk mengiringi lagu (Nurlela, E. 2005: 63)

Jika dilihat dari bentuk dan cara memainkannya, waditra Gembyung sendiri termasuk ke dalam alat musik membranofon. Menurut Atik Soepandi (1998: 127) membranofon adalah alat bunyi-bunyian dengan mempunyai kualitas suara yang ditimbulkan oleh lapisan membran atau wangkis. Alat musik yang termasuk ke dalam jenis ini misalnya kendang, dogdog, bedug, terebang, dan sebagainya. Terebang yang digunakan kesenian Gembyung sebanyak lima buah. Kelima buah terebang tersebut memiliki ukuran yang berbeda dan mempunyai nama masingmasing, yaitu : 
a. Tojo;

b. Kempyang;

c. Terebang Indung;

d. Jidor;

e. Dogdog.

Ditinjau dari bunyi yang dihasilkan, terebang (gembyung) merupakan alat yang tidak memiliki skala nada yang tetap, namun untuk membedakan tinggi rendahnya bunyi antara terebang yang satu dengan yang lainnya dihasilkan dari besar dan kecilnya terebang serta kencang dan kendurnya kulit muka terebang.

Untuk mengatur kencang kendurnya kulit tersebut, dipergunakan paseuk yang dipasang mengelilingi pada bagian samping atas 'badan' terebang. Secara berurutan terebang yang ukurannya lebih besar digunakan untuk menghasilkan bunyi yang lebih rendah. Sedangkan terebang yang lebih kecil untuk bunyi yang lebih tinggi. Dengan demikian, semakin besar bentuk terebang, maka bunyi yang dihasilkan akan semakin rendah. Begitu pula dengan kencang kendurnya kulit pada muka terebang. Semakin kencang kulit permukaan terebang, maka bunyi yang dihasilkan semakin tinggi.

Setiap waditra kesenian

Gembyung mempunyai fungsi masingmasing untuk menuju kesatuan goongan yang sama, sehingga menghasilkan satu kesatuan tabuhan yang utuh dalam mengiringi setiap lagu. Kelima bentuk waditra tersebut mempunyai fungsi yang berlainan dalam penyajian seni Gembyung. Untuk lebih jelasnya dapat diuraikan sebagai berikut :

Alat musik dogdog berfungsi sebagai anggeran wiletan (irama pukulan yang menjadi acuan pada tabuhan yang lain), maksudnya ketukan yang berulang-ulang dalam jarak (tempo) yang sama, dan untuk memperjelas tegaknya dalam setiap wiletan (Nurlela, 2005, 64). Cara membunyikannya adalah dengan memukul/menabuh pada bagian atas wangkis dogdog sambil di pegang sebagian permukaannya (Sunda: ditengkep). Bunyi yang dihasilkan oleh dogdog hanya satu suara, yaitu bunyi: "tung". Bila dilihat dari diameter permukaannya, alat ini paling kecil (24 $\mathrm{cm})$ saja, tetapi paling tinggi dari alatalat Gembyung yang lainnya.

Fungsi tojo hampir sama dengan dogdog pada Gembyung adalah sebagai anggeran wiletan dan untuk mempertegas jalan tegaknya ketukan secara berulang-ulang dalam tempo yang sama, juga sebagai tembal ajeg, yang bersahutan dengan dogdog. Perbedaan dengan dogdog adalah kalau dogdog ditabuh satu kali, sedangkan tojo dipukul dua kali. Keduanya saling mengisi (patembalan) sehingga paduan bunyi yang khas. Tojo menghasilkan bunyi "teung" yang dihasilkan dengan cara memukul bagian (sisi) pinggir terebang dengan menggunakan sebagian jari tangan kanan dan menepuknya dilepas tanpa ditengkep.

Waditra Gembyung ketiga adalah kempyang. Fungsi dari kempyang adalah sebagai pukulan yang mempunyai aksen yang bersahutan, berjarak setengan ketuk dari tabuhan tojo. Teknik membunyikannya dengan cara dipukul bagian pinggir agak ke tengah permukaan tanpa ditengkep atau dilepas. Bunyi yang dihasilkan adalah "pak". Alat ini memiliki ukuran yang lebih besar dari tojo.

Alat musik yang keempat adalah Terebang Indung, berukuran lebih 
besar dari kempyang. Fungsi terebang indung dalam pertunjukan Gembyung adalah sebagai patokan dan juga sebagai penjaga atau pemelihara embat lagu serta ciri bentuk lagu. Bunyi yang dihasilkan oleh terebang indung yaitu bunyi "dong", dihasilkan dengan cara memukul atau menepuk bagian atas atau pinggir terebang indung dan ditengkep dengan dua jari tengah dan jari manis kiri.

Alat musik kelima yaitu Jidor, merupakan alat paling besar dan paling tinggi. Jidor berfungsi sebagai pemberi aksen semacam goong, untuk memperkuat ritme dari paduan alat yang dimainkan. Bunyi yang dihasilkan oleh jidor adalah "bang" dan "prak", bunyi ini dihasilkan dengan cara memukul atau menepuk bagian tengah permukaan jidor dan dilepas tanpa ditengkep.

Untuk mengetahui lebih jelas ukuran masing-masing alat musik Gembyung dapat dilihat pada tabel berikut:

\begin{tabular}{|c|c|c|c|c|c|c|c|}
\hline Na & $\begin{array}{c}\text { Nama } \\
\text { Terebang }\end{array}$ & $\begin{array}{c}\text { Diameter } \\
\text { Atas }\end{array}$ & $\begin{array}{c}\text { Diameter } \\
\text { Bawah }\end{array}$ & $\begin{array}{c}\text { Keliling } \\
\text { Atas }\end{array}$ & $\begin{array}{c}\text { Keliling } \\
\text { Bawah }\end{array}$ & Tinggi & $\begin{array}{c}\text { Jumlah } \\
\text { Paseuk }\end{array}$ \\
\hline 1. & Dagdag & $24 \mathrm{~cm}$ & $13 \mathrm{~cm}$ & $80 \mathrm{~cm}$ & $51 \mathrm{~cm}$ & $46 \mathrm{~cm}$ & 19 \\
2. & Tajo & $26 \mathrm{~cm}$ & $14 \mathrm{~cm}$ & $85 \mathrm{~cm}$ & $48 \mathrm{~cm}$ & $12 \mathrm{~cm}$ & 20 \\
3. & Kempyang & $27 \mathrm{~cm}$ & $16 \mathrm{~cm}$ & $94 \mathrm{~cm}$ & $52 \mathrm{~cm}$ & $13 \mathrm{~cm}$ & 27 \\
4. & Indung & $40 \mathrm{~cm}$ & $19 \mathrm{~cm}$ & $128 \mathrm{~cm}$ & $68 \mathrm{~cm}$ & $25 \mathrm{~cm}$ & 29 \\
5. & Jidar & $51 \mathrm{~cm}$ & $25 \mathrm{~cm}$ & $157 \mathrm{~cm}$ & $81 \mathrm{~cm}$ & $60 \mathrm{~cm}$ & 31 \\
\hline
\end{tabular}

Sumber: dokumentasi hasil penelitian lapangan th. 2009

Bahan-bahan yang digunakan dalam pembuatan instrumen Kesenian Gembyung berpengaruh terhadap kualitas suara dan daya tahan instrumen tersebut. Adapun bahan-bahan yang digunakan dalam pembuatan instrumen (waditra) pada saat sekarang sudah jauh berbeda dengan keadaan atau ketersediaan bahan pada zaman dahulu.
Kayu untuk 'badan' terebang sebaiknya terbuat dari kayu Mahoni atau kayu Nangka. Kedua kayu ini semakin hari, semakin sulit dicari. Terutama kayu Nangka yang berasal dari pohon yang berdiameter besar (di atas $60 \mathrm{~cm}$ ), keberadaanya sudah semakin jarang.

Kualitas kayu Nangka, sangat ideal, karena mutu kayunya yang kuat dan liat, serta tahan lama. Kayu Mahoni, dengan warna kayu yang merah tua, cukup ideal, karena mutu kayu yang terbilang kuat dan tahan lama. Kelebihan kayu Nangka dari kayu Mahoni, yaitu kayu Nangka lebih padat dan liat serta lebih tahan terhadap rayap. Adapun kayu Mahoni kurang tahan terhadap rayap, sehingga memerlukan pengolahan yang seksama sebelum dijadikan bahan. Kayu untuk membuat pasak biasanya dibuat dari kayu Pongporang. Sedangkan bahan untuk membuat badan Dogdog atau Jidor, sekarang banyak menggunakan pohon Kelapa bagian bawah (tunggul).

Membran untuk permukaan atau wangkis terebang biasanya dibuat dari kulit kerbau. Bahan ini memberikan hasil yang paling bagus, karena kulit kerbau lebih kuat dan padat sehingga menghasilkan mutu suara yang ideal. Namun bahan kulit kerbau sekarang ini semakin sulit didapat. Untuk menggantikannya, sekarang bahan wangkis lebih banyak dibuat dari kulit domba atau kambing. Bahan tali untuk mengikat kulit wangkis, yang disebut "jeujeul", dibuat dari rotan (hoe).

Agar mutu suara dari masingmasing waditra tetap terpelihara dengan baik, biasanya dilakukan pemeliharaan. Cara pemeliharaan waditra Gembyung, yaitu setiap selesai pagelaran, "jeujeul" atau tali pengikat 
wangkis yang dikencangkan oleh "paseuk" dikendurkan kembali atau direnggangkan dari kulit membran atau wangkis. Kemudian masing-masing waditra dimasukkan ke dalam kain pembungkus.

\section{Teknik Pementasan}

Dilihat dari sisi penyajiannya, Kesenian Gembyung tergolong pada sekar gending, yaitu sajian sekar yang diiringi dengan gending. Gending yang dimaksud adalah permainan seperangkat waditra yang terdiri atas lima buah terebang yang digunakan sebagai pengiring sekar. Dengan demikian, kesenian Gembyung merupakan seni suara yang disajikan dengan suara mulut manusia yang diiringi alat bunyibunyian (Atik Soepandi, 1985: 16)

Pertunjukan Seni Gembyung dalam upacara maulid Nabi Muhammad Saw. dilaksanakan di Bumi Alit, yaitu bangunan kecil tempat menyimpan benda-benda di bagian depan mesjid. Kedua tempat ini merupakan tempat yang sangat penting bagi masyarakat Desa Panjalu. Adapun tahapan penyajian Seni Gembyung, terdiri atas tiga tahap, yaitu sebagai berikut:

Tahap Pertama; Sebelum pertunjukan dimulai, para pemain terlebih dahulu mempersiapkan segala hal yang diperlukan dalam pergelaran Gembyung, di antaranya mempersiapkan alat (terebang) dengan cara memukul "paseuk" atau penyangga kulit permukaan. Kegitan ini disebut 'menyetem' terebang atau memeriksa bunyi/titi laras tiap waditra terebang. Selanjutnya berdoa yang dilengkapi dengan ngukus atau membakar kemenyan dengan perlengkapannya.
Tahap kedua; Mengawali sajian, dimulai dengan menyajikan lagu “assalamu alaek” yang diiringi pola tabuhan tepak tilu. Penyajian lagu selanjutnya dilakukan secara berkesinambungan, yaitu menyajikan lagu berikutnya. Dalam tiap penampilan, lagu yang disajikan berjumlah 23 buah. Adapun judul lagu-lagu selanjutnya yaitu “ya kahpaw”, “haeruman” dan lain sebagainya. Syair lagu pada umumnya bersumber pada kitab shalawat Barzanji. Sejak dahulu hingga sekarang, menurut penuturan seniman gembung menyatakan bahwa tidak ada lagu yang baru, ke-23 lagu yang disajikan merupakan peninggalan para seniman terdahulu. Mereka tinggal melanjutkan saja.

\section{Lagu-lagu Gembyung}

Walaupun disebutkan di atas bahwa jumlah lagu yang disajikan pada tiap pertunjukan berjumlah 23 buah, namum pola tabuhan Gembyung ada sekitar empat buah pola tabuhan saja, yakni: tepak tilu, rincik, gobyog, dan tuktuk brung. Lagu-lagu yang disajikan merupakan peninggalan para seniman terdahulu, sampai sekarang tidak diketahui siapa pengarang lagu tersebut. Dengan demikian semua lagu merupakan lagu buhun, hasil ciptaan para seniman terdahulu. Salah satu contoh syair lagu seni Gembung yaitu lagu asrokol, yaitu sebagai berikut:
"Ya Nabi salam alaika
Ya Nabi salam alaika
Asrokol badru alaina
Fathofat minhul buduru
Wajabasy syukru alaina
Anta syamsun anta badrun
Anata iksirun wa ghoolun
Ya mu'ayyad ya mumajid 
Marroa wajhu wa yasady Mabduka shoinul mubarrod"

Terjemahan bebasnya adalah sebagai berikut:

"Semoga keselamatan tercurah kepadamu Wahai Nabi

Semoga keselamatan tecurah kepadamu wahai Nabi

Telah hadir bulan purnama raya kepada kami

Yang membawa cahaya terang benderang serta bahana kebaikan

Wajiblah rasa syukur diungkapkan karenamu

Engkau bagaikan mentari gemilang

Engkau bagaikan purnama terang

Engkau penggugah kalbu yang tak terhingga

Wahai kekasih kami

Wahai Muhammad

Wahai yang dikokohkan Tuhan

Wahai yang dimuliakan Tuhan

Bahagialah insan yang dapat melihat wajahmu"

Salah satu fungsi kesenian -yang merupakan salah satu unsur kebudayaan-- ialah meningkatkan dan mengembangkan nilai spiritual, etis dan estetika pada diri manusia sebagai makhluk ciptaan Tuhan. Kesenian, sebagai produk manusia, diperlukan untuk memenuhi kebutuhan hidupnya, demikian pula ketika ia menyampaikan pesan pendidikan, penerangan, dan hiburan.

Dari beberapa pernyataan yang dikemukakan di atas, ternyata asal-usul seni Gembyung selalu dikaitkan dengan para tokoh penyebar agama
Islam di Pulau Jawa, yaitu para Wali. Mereka menjadikan seni sebagai salah satu alat yang cukup ampuh dalam menyebarluaskan agama Islam kepada penduduk Pulau Jawa pada abad XV. Peran para Wali kemudian dilanjutkan oleh para penerusnya, dan selanjutnya diteruskan oleh para leluhur kampung atau daerah tertentu. Demikian pula halnya dengan Seni Gembyung di Panjalu Kabupaten Ciamis.

Manusia sebagai makhluk yang berbudaya dalam hidupnya selalu berhubungan dengan simbol-simbol. Dapat dikatakan bahwa simbol merupakan bagian integral dari hidup manusia. Oleh karena itu dengan begitu eratnya kebudayaan manusia dengan simbol, maka manusia pun dapat pula disebut makhluk bersimbol. Dengan melalui simbol kita dapat membaca dan menemukan nilai-nilai sebagai ekspresi kehidupan manusia. Dengan demikian, simbol dapat digunakan untuk memahami fenomena-fenomena seperti dalam berbahasa atau berkomunikasi, religi, kesenian, sejarah, ilmu pengetahuan, atau teknologi. Penggunaan simbol-simbol dalam kebudayaan adalah universal dan penting peranannya. Dengan menggunakan simbol-simbol yang dapat digunakan dengan kata-kata, gerak tubuh, dan upacara-upacara dapat dipertahankan keadaan yang baik dari masyarakat pendukung kebudayaan tersebut dalam segala kebutuhan.

Pertunjukan seni Gembyung memiliki makna simbolis sebagai penolak bala dan penghormatan serta pemujaan terhadap roh-roh nenek moyang. Hal ini tercermin pada sajian lagu-lagu pujian kepada Nabi Muhammad sebagai simbol pengakuan 
terhadap eksistensi roh para karuhun disekitar manusia.

Pertunjukan Seni Gembyung pada berbagai upacara keagamaan seperti Maulid Nabi, Rajaban dan sebagainya, maupun pada upacara kemasyarakatan seperti pada upacara daur hidup, serta upacara Nyangku menandakan bahwa manifestasi dari konsep doktrin agama atau kepercayaan yang dipegang teguh oleh masyarakat yang merupakan bentuk nyata dari ungkapan ritual masyarakat. Hal ini pun menunjukan bahwa hak asasi dari setiap manusia meyakini bahwa ada sesuatu yang diluar kemampuannya, serta meyakini sebagai makhluk tak berdaya menghadapi kekuatan yang maha dahsyat. Kekuatan tersebut berasal dari kekuasaan Tuhan, maupun kekuatan alam semesta.

Upacara kemasyarakatan yang mempertautkan kegiatan perayaan upacara daur hidup dengan ajaran agama Islam, menyebabkan dilibatkannya para pemuka agama sebagai juru doa ke hadirat Tuhan Yang Maha Kuasa sebagai satu sumber kekuatan yang menaungi jagat ini. Alasan lainnya, dapat dipahami bahwa acara ini dilakukan sebagai sarana memuja dan menghormati leluhur yang dianggap sebagai jembatan penghubung antarmanusia dengan satu kekuatan yang maha dahsyat tersebut. Sering kali masyarakat percaya bahwa kejadian-kejadian alam ini ada hubungannya dengan dunia transenden yang tidak terjangkau oleh manusia dalam wujud kasar.

Makna sosial lebih jelas terlihat realitasnya pada upacara keagamaan, dimana warga mayarakat bahu membahu menyelenggarakan acara ini tanpa mengenal usia atau strata sosial.
Semangat kebersamaan dalam bermasyarakat ditunjukkan mulai dari persiapan dengan mengadakan musyawarah sebagai jalan pemecahan masalah. Kemudian pada pelaksanaan upacara dilakukan secara gotong royong dari mulai pendanaan hingga persiapan panggung dan urusan makanan dikerjakan secara bersamasama. Maka jelaslah bahwa acara ini merupakan momen dalam rangka memupuk tali kekeluargaan dan persaudaraan.

Seni Gembyung dapat digolongkan pada jenis seni kontemplatif. Kesenian yang cenderung mengajak kita untuk merenung atau tafakur, ketimbang menghibur. Kesenian buhun ini biasa ditabuh untuk mengiringi orang-orang yang melantunkan shalawat, nadom atau tembangtembang puji-pujian lainnya. Gembyung bukanlah jenis kesenian yang murni tontonan, karena pada zaman dulu kesenian ini biasa digelar di dalam atau di halaman rumah pada maulid Nabi untuk selamatan menyambut bayi yang baru lahir, khitanan anak, selamatan nikah, maupun pada upacara tradisional kemasyarakatan.

Yang khas dari Gembyung bukan hanya terebangnya yang terbuat dari kayu dengan berbagai ukuran, namun juga kulitnya harus menggunakan kulit kerbau yang tebal. Cara memasangnya juga sangat khas dengan menggunakan pasak yang juga berbeda dengan terebang lain.

"Saya tidak tahu kenapa, tapi menurut karuhun memang harus memakai kulit kerbau yang belum dikasih garam," kata Ade 
Solihin, pimpinan salah satu rombongan Gembyung.

Menurut Ade pula, kesenian ini muncul seiring dengan berkembangnya syiar Islam ke Ciamis. Maka tak heran jika lagu-lagu yang ditembangkannya juga sekitar shalawat Al-Barjanzi dan Ad-Diba, serta yang digali dari riwayat Syeh Abdul Qodir Jailani. Keseniankesenian di kampungnya ini kemudian bisa berkembang karena mendapat perhatian dari bupati Ciamis pada saat itu.

Dengan demikian, Seni Gembyung lekat dengan syiar Islam di desa Panjalu. Masyarakat setempat pun percaya bahwa seni ini, merupakan warisan para leluhur dalam upaya menyebarkan agama Islam, hingga Islam pun sampai di kampung mereka. Dalam menjaga agar kesenian ini terus dapat hidup, mereka pun meyakini bahwa Kesenian Gembyung ini berkaitan erat dengan keyakna (agama) Islam yang harus tetap mereka jaga.

Namun demikian, bagaimana seni musik pada masyarakat Islam, apakah seni musik berkembang serta dapat diterima bahkan berkembang ? Berikut ini akan dijelaskan sedikit keadaan seni musik pada masyarakat Islam terutama pada tahap awal perkembangannya.

Pada awal era kejayaan Islam, ternyata telah lahir tokoh-tokoh besar di bidang seni musik. Para ilmuwan Muslim juga telah menjadikan musik sebagai media pengobatan atau terapi. Kegemilangan peradaban Islam ditandai dengan kemajuan ilmu pengetahuan dan kebudayaan. Kemajuan ilmu pengetahuan dan kebudayaan ini bersentuhan erat dengan moral Islam, budaya Arab, dan kebudayaan besar lainnya.
Oleh karena itu, yang disebut sebagai kebudayaan Islam tidak selamanya berasal dari Arab. Bisa jadi ia hasil adopsi atau akulturasi antara upacara keagamaan dengan budaya masyarakat setempat. Musik adalah contohnya. Sejarah membuktikan bahwa musik yang selama ini dikenal sebagai musik Islam ternyata tidak murni berasal dari Arab. Kesenian ini lahir dari kearifan umat Muslim terdahulu yang mengolaborasikan musik-musik dari Arab, Persia, India, dan Yunani.

Seni musik telah mendapat perhatian besar sejak Dinasti Umayyah pada masa kekhalifahan Islam. Hal itu ditandai dengan maraknya kegiatan penerjemahan kitab-kitab seni musik ke dalam bahasa Arab. Tradisi pengkajian dan permainan musik selanjutnya semakin berkembang pada era Dinasti Abbasiyah.

Banyak ilmuwan Muslim yang menerjemahkan buku-buku tentang musik dari Yunani, terutama pada masa pemerintahan Khalifah Al-Ma'mun. Prof. A. Hasymy (1993), mencatat bahwa pada masa Dinasti Abbasiyah, kegiatan kepengarangan tentang seni musik berkembang pesat.

Sekolah-sekolah musik didirikan oleh khalifah Al-Ma'mun di berbagai kota dan daerah, baik sekolah tingkat menengah maupun sekolah tingkat tinggi. Sekolah musik yang bagus dan berkualitas tinggi adalah yang didirikan oleh Sa'id 'Abd-ul-Mu'min (wafat tahun $1294 \mathrm{M})$.

Tak heran jika pada awal era kejayaan Islam telah lahir tokoh-tokoh besar di bidang seni musik. Ada musisi ternama dan sangat disegani, yaitu Ishaq Al-Mausili (767 M-850 M). Ada 
pula pengkaji seni musik yang dihormati, seperti Yunus bin Sulaiman Al-Khatib (wafat tahun $785 \mathrm{M}$ ). Munculnya seniman dan pengkaji musik di dunia Islam menunjukkan bahwa umat Muslim tidak hanya melihat musik sebagai hiburan. Lebih dari itu, musik menjadi bagian dari ilmu pengetahuan yang dikaji melalui teori-teori ilmiah.

Yang menarik lagi, para ilmuwan Muslim juga telah menemukan musik sebagai media pengobatan atau terapi. Tokoh dalam bidang ini di antaranya adalah $\mathrm{Abu}$ Yusuf Yaqub ibnu Ishaq al-Kindi (801$873 \mathrm{M})$ dan al-Farabi (872-950 M). Kajian tentang musik sebagai sistem pengobatan berkembang semakin pesat pada masa Dinasti Turki Usmani.

Pada masa kini, diyakini bahwa musik dapat memberikan efek kepada pikiran dan badan manusia. Menurut sebagian ahli, musik dapat berfungsi meningkatkan mood dan memengaruhi emosi. Bahkan, para ilmuwan di era Turki Usmani sudah mampu menetapkan jenis musik tertentu untuk penyakit tertentu. Misalnya, jenis musik huseiny dapat mengobati demam. Sedangkan, jenis musik zengule untuk mengobati meningitis (Hasymy, 1993)

Terlepas dari perhatian ilmuwan dan umara pada musik hingga menjadi karya seni yang mengagumkan, musik selalu saja menjadi bahan polemik banyak ulama. Maklum saja, seni musik memang punya pengaruh yang kuat pada masyarakat sehingga ulama merasa perlu mengawal perkembangannya, apakah sejalan dengan syariat Islam atau tidak.

Pendapat para ulama yang pro dan kontra terletak pada perbedaan perspektif mereka. Ada ulama yang melihat musik dari perspektif Alquran dan Hadits; ada yang melihatnya dari perspektif sosial budaya; dan ada pula yang berusaha bersikap lebih arif, yakni melihat musik dari perspektif agama dengan mempertimbangkan kemaslahatan sosial umat Islam.

Kelompok yang ketiga berusaha tidak terjebak pada jenis atau suara musik, tetapi melihat efek yang ditimbulkan oleh musik itu. Jika musik yang disajikan tidak mengakibatkan efek-efek buruk pada kehidupan individu dan sosial, hukumnya halal. Demikian pula sebaliknya.

Dalam konteks Indonesia, perbedaan pendapat ulama tentang musik mengakibatkan polarisasi pandangan umat Islam terhadap musik itu. Ada musik yang dianggap Islami dan tidak Islami. Warna musik kasidah atau nasyid yang kental dengan pengaruh Arab mendapatkan predikat sebagai musik Islami. Sedangkan, dangdut, keroncong, pop, rock, jazz, dan lain-lain termasuk katagori yang tidak Islami.

Musik, pada posisi ini (musik Islami dan bukan musik Islami) seperti arena yang memiliki aturan sendiri yang memungkinkan pelaku bertindak sesuai dengan kebutuhannya. Arena tersebut berisikan berbagai modal, mulai dari modal ekonomi sampai modal kultural, dan sarat dengan perebutan kepentingan.

Kekuasaan pada modal ekonomi, sebagai salah satu aktualisasi kepentingan, sering membuat kita hanya disuguhi musik-musik yang sering ditampilkan di televisi atau hanya mengenal kelompok musik yang telah memiliki album rekaman. Kekuasaan pada modal kultural seperti 
simbol-simbol keagamaan membuat kita yakin bahwa musik yang bersyair bahasa Arab dan dinyanyikan oleh artis dengan busana muslim, adalah musik Islami.

Akan halnya dengan musik atau Seni Gembyung, dengan syair-syair yang semuanya bersumber pada syair sholawat Nabi, walaupun sudah amat sulit melihat sisa ciri-ciri syairnya karena sudah mengalami 'pengalihan' ke dalam tradisi setempat (Sunda). Akankah kita masih menyebutkan bahwa musik ini adalah musik islami? Tentu akan kita temukan berbagai pendapat tentang hal ini bergantung dari sisi mana kita melihatnya, dan tulisan ini tidak akan membahasnya lebih jauh.

Setiap kelompok masyarakat memiliki sejarah hidupnya sendiri hingga memilih suatu jenis musik tertentu dan menghidupinya dengan cara tertentu pula. Kita tidak bisa menganggap enteng musik yang hidup dalam lokalitas. Musik yang hadir dari semangat lokalitas justru merupakan cara untuk berkomunikasi dengan dunianya. Bisa jadi komunikasi untuk meresistensi sesuatu, seperti meresistensikan kehidupan sosial, seiring suasana kehidupan sosial mereka di luar musik.

\section{PENUTUP}

Gembyung sebagai kesenian buhun yang menjadi sebuah seni pertunjukan di Panjalu, hingga kini tetap berlangsung dengan ciri ketradisionalannya. Bersama dengan pelaksanaan upacara Nyangku, maupun peringatan maulid Nabi Saw. atau pada acara hiburan pada saat khitanan anak. Gembyung tetap tampil bersahaja.
Namun demikian, tetap menyampaikan makna, melaui gerak, lagu, gending musik, maupun aroma sesajennya bahwa hidup akan terus bergerak seiring berlangsungnya sang waktu.

Bagi masyarakat Panjalu, seni Gembyung tidak hanya sebuah ungkapan ekpresi keindahan, namun lebih dari itu, Gembyung memiliki makna kecintaan serta penghormatan kepada asal-usul leluhur mereka dalam syair-syair lagu pujian kepada Nabi mereka, yang pada masa kini telah menjadi pegangan serta keyakinan hidup mereka.

Para seniman Gembyung yang didominasi oleh kaum tua, mengisyaratkan bahwa seni ini kurang menarik bagi kalangan muda. Sehingga kondisi ini menyulitkan bagi para seniman Gembyung untuk mengadakan regenerasi kepada kaum muda.

Seperti kita ketahui dewasa ini, banyak kesenian tradisional mengalami situasi sulit yang pada akhirnya berujung pada kepunahan. Permasalahan ini lebih banyak disebabkan kurangnya kesempatan kesenian Gembyung ini untuk lebih banyak dipentaskan, tidak hanya pada waktu-waktu yang sudah biasa. Untuk itu, kesempatan waktu pentas yang lebih banyak, dapat dilakukan pada acara-acara hiburan ditingkat Kabupaten maupun even-even lainnya.

Masyarakat Panjalu, terutama dari golongan tua dan sesepuh masyarakat, adalah para 'pemegang' Seni Gembyung sehingga dapat bertahan sampai saat ini. Oleh karena itu, masyarakat setempat adalah tempat hidup seni ini. Untuk itu pula agar 'ruang hidup' ini senantiasa dijaga dan terus dilestarikan. Sesepuh masyarakat 
dan para tokoh seni Gembyung agar lebih intensif mengajak kalangan generasi muda untu turut mencintai seni Gembyung. Kalangan generasi muda semestinya diberi pengertian tentang arti penting menjaga kelestarian seni peninggalan para leluhur mereka.

Peranan berbagai dinas dan instansi terkait tidak kalah pentingnya. Untuk memberi kesempatan yang lebih banyak pada kesenian tersebut pentas bahkan bisa tampil di luar masyarakat pendukungnya. Bantuan berupa peralatan kesenian pun diharapkan secara rutin dilakukan kepada kelompok Seni Gembyung guna memberi kesempatan para generasi muda untuk turut berlatih.

\section{DAFTAR PUSTAKA}

Atmadibrata, E. dan Soepandi, Atik. 1983.

Khasanah Kesenian Daerah Jawa Barat, Bandung: Pelita Masa.

Hasymy, A. 1993.

Sejarah Kebudayaan Islam, Cet. ke-3, Bandung: Al-Maarif.

Herlinawati, Lina. 2007.

Kesenian Gembyung Masyarakat

Banceuy Kabupaten Subang; Sebuah Ekpresi Seni dan Aktualisasi Kepercayaan Masyarakat. Dalam Jurnal Penelitian. Edisi 37, Juni. Bandung: BPSNT.

Nugroho, E. 1990.

Ensiklopedi Nasional Indonesia No. 8. 1990. Jakarta : PT Cipta Adi Pustaka.

Nurlela, Enur. 2005.
Struktur Penyajian Kesenian Gembyung Rumalega Sebagai Syiar Islam di Desa Panjalu Kabupaten Ciamis. Skipsi S1 Jurusan Pendidikan Seni Musik. Bandung: UPI.

Padmawidjaja, Rusadi. 2002.

Nilai Kultural Religius Babad Panjalu, Makalah disampaikan pada Seminar Sejarah dan Budaya Panjalu tanggal 9 Juni 2002

Puwadarminta, W.J.S. 1982.

Kamus Umum Bahasa Indonesia. Jakarta: PN. Balai Pustaka.

Rosidi, Ajip. dkk. 2000.

Ensiklopedi Sunda. Alam, Manusia, dan Budaya Termasuk Budaya Cirebon dan Betawi. Cetakan Pertama. Jakarta : Pustaka Jaya.

Soepandi, Atik, dkk. 1998.

Peralatan Hiburan dan Kesenian Tradisional di Jawa Barat. Jakarta: Depdikbud Dirjen Kebudayaan, Direktorat Sejarah dan Nilai Tradisional, Proyek Inventarisasi dan Dokumentasi Kebudayaan Daerah.

Suryana, Jajang. 2002.

Wayang Golek Sunda; Kajian Estetika Rupa Tokoh Golek. Bandung: Kiblat Buku Utama.

Suryanegara, Ahmad Mansur. 2002.

Seminar Menggali Nilai-Nilai Sejarah dan Budaya Panjalu. Makalah disampaikan pada Seminar dengan tema sda. Panitia Bersama Nyangku dan Festival 9 Juni 2002.

Majalah \& Surat Kabar : 
Hamidimadja, D.H. Nurendah. 1996.

Seni Islam Sebagai Media Komunikasi dalam "KAWIT" Buletin Kebudayaan Jawa Barat no. 48.

Republika Newsroom, 2009. Masyarakat Panjalu Rayakan Maulid Nabi Saw dengan
'Nyangku', REPUBLIKA Senin, 23 Maret.

Suherman, DS. 1990.

Nyangku di Panjalu, Upacara Semarak. Pikiran Rakyat, Senin, 15 Oktober. 